\title{
PENGEMBANGAN KUALITAS GURU: UPAYA KEPALA SEKOLAH DALAM MENINGKATKAN MUTU SEKOLAH DASAR
}

\author{
Nur Amaliyah Hanum* \\ Achmad Supriyanto \\ Agus Timan \\ Manajemen Pendidikan, Universitas Negeri Malang \\ Jl. Semarang No.5, Malang, Indonesia \\ *email: mkhanum9294@gmail.com
}

Artikel diterima: 31 Maret 2020; disetujui: 31 Mei 2020

\begin{abstract}
This study aims to determine the efforts of principals in improving the quality of primary schools through the development of quality teachers in elementary schools. This research was conducted using qualitative methods with interview techniques. The subject of this study was the principal of the elementary school in Malang Regency. The results of the study showed that the efforts of principals in developing the quality of elementary school teachers have three indicators including (1) teacher motivation, (2) teacher personality, and (3) teacher skills. All indicators have been implemented except that in the implementation of the teacher quality development program there are still some obstacles and the result are less than expected.
\end{abstract}

Keywords: teacher; quality improvement; elementary school.

\begin{abstract}
Abstrak: Penelitian ini bertujuan untuk mengetahui upaya kepala sekolah dalam meningkatkan mutu sekolah dasar melalui pengembangan kualitas guru di sekolah dasar. Penelitian ini dilakukan menggunakan metode kualitatif dengan teknik wawancara. Subjek penelitian ini adalah kepala sekolah dasar di Kabupaten Malang. Hasil penelitian menunjukkan bahwa upaya kepala sekolah dalam mengembangkan kualitas guru sekolah dasar terkait dengan tiga indikator, antara lain (1) motivasi guru, (2) kepribadian guru, dan (3) keterampilan guru. Semua indikator sudah dilaksanakan, hanya saja dalam pelaksanaan program pengembangan kualitas guru masih terdapat beberapa hambatan dan hasilnya kurang maksimal.
\end{abstract}

Kata kunci: guru; peningkatan mutu; sekolah dasar.

Indonesia saat ini telah memasuki era globalisasi dimana segala bidang kehidupan mulai dipenuhi dengan kompetisi yang ketat, salah satunya pada bidang pendidikan. Pendidikan merupakan aspek penting dalam kehidupan manusia, karena selain berperan dalam membentuk pribadi individu juga menjadikan manusia semakin berbudaya serta mampu mengembangkan budaya dan kompetensinya dalam menuju kualitas kehidupan yang lebih baik (Juanda, 2010). 
Setiap lembaga pendidikan baik pada jenjang SD/MI, SMP/MTs, SMA/MA, maupun PT harus terus berupaya dalam menghasilkan lulusan yang mampu berkompetisi secara global sesuai dengan perkembangan yang ada. Disini SD/MI sebagai lembaga pendidikan dasar yang merupakan salah satu jenjang pendidikan formal yang mempunyai peran strategis sebagai landasan peserta didik dalam menentukan pendidikan jenjang menengah dan dapat memengaruhi pendidikan pada jenjang-jenjang selanjutnya (Sonhadji, 2014).

Berdasarkan pendapat di atas, dapat disimpulkan bahwa sebagai lembaga pendidikan dasar, sekolah dasar sangat berperan terhadap upaya pembangunan pendidikan di Indonesia. Pembangunan pendidikan yang paling ditekankan disini adalah pada peningkatan mutu pendidikan yang terdiri dari keseluruhan komponen pendidikan yaitu human resources dan material resources (Nwabueze, 2016). Material resources antara lain seperti keuangan, sarana dan prasarana, dan sebagainya. Sementara human resources disini yaitu sumber daya manusianya, dimana sumber daya manusia yang lebih berpengaruh terhadap mutu pendidikan meliputi tenaga pendidik (guru) dan tenaga kependidikan (pengawas, peneliti dan pengembang, pustakawan, laboran, dan sebagainya). Akan tetapi dari beberapa komponen pendidikan di atas, yang selalu mendapat banyak perhatian adalah guru, karena di tangan gurulah mutu pendidikan bergantung.

Makbuloh (2016) menyatakan masalah rendahnya mutu sekolah pada akhirnya menjadi titik penilaian secara umum. Dimana standar mutu akan dinilai dari mutu guru dan mutu lulusannya, lulusan yang akhirnya dapat diterima kerja atau diterima pada pendidikan di tingkat selanjutannya melalui kompetisi yang fair. Sementara untuk menghasilkan lulusan yang demikian, faktor penentu utamanya adalah guru. Hal ini dikarenakan kedudukan guru sebagai sentral dalam proses pembelajaran sekaligus sebagai pembentuk kualitas peserta didik.

Guru berperan sebagai faktor kunci, karena gurulah yang berinteraksi langsung dengan peserta didik dalam proses belajar mengajar di sekolah. Maruli (2014) menyatakan bahwa kualitas guru adalah fitur paling penting dari sekolah yang meningkatkan prestasi peserta didik dan penentu terpenting kedua pembelajaran peserta didik setelah keluarga. Dapat disimpulkan bahwa kadar kualitas guru dipandang sebagai penyebab kadar kualitas output sekolah. Rendahnya atau merosotnya mutu pendidikan sering disinyalir sebagai akibat dari kurang maksimalnya kinerja guru (Fadhli, 2017).

Faktor penentu keberhasilan dari hasil pendidikan memang bukan hanya guru, banyak faktorfaktor lainnya yang juga memang ikut menentukan, akan tetapi proses pembelajaran di sekolah merupakan inti sebuah pendidikan dimana baik buruknya pembelajaran sangat bergantung pada seorang guru (Gunawan, 2015). Oleh karena itu, kepala sekolah sebagai seorang supervisor sekolah harus dapat membantu guru, melayani guru, mengupayakan bagaimana para guru mampu 
meningkatkan kualitas dan kemampuan mengajarnya sehingga tujuan dalam meningkatkan mutu sekolah dapat tercapai.

\section{METODE}

Metode yang digunakan dalam penelitian ini yaitu menggunakan metode penelitian kualitatif dengan teknik wawancara. Penelitian dilakukan di salah satu SD Negeri di Kabupaten Malang, yaitu SD Negeri Gondowangi 3, yang berlokasi di Jalan Dawuhan No. 9 RT. 14 RW. 3, Gondowangi, Kecamatan Wagir, Kabupaten Malang. Dalam penelitian ini, Bapak S selaku Kepala Sekolah SD Negeri Gondowangi 3 Wagir sebagai subjek penelitian atau responden dari penelitian ini. Model analisis data yang digunakan dalam penelitian ini adalah model Analysis Interactive dari Miles dan Huberman dengan aktivitas dalam analisis data meliputi reduksi data, penyajian data, dan gambaran simpulan/verifikasi (Ilyas, 2016).

\section{HASIL DAN PEMBAHASAN}

Profesi seorang guru bukan pekerjaan yang dengan mudahnya dapat dilakukan. Tuntutan yang berat yang harus diperjuangkan oleh seorang guru adalah mampu menghasilkan lulusan yang berkualitas. Anizah dan Maretta (2017) menyatakan bahwa pendidikan yang berkualitas sangat memerlukan adanya guru yang profesional di dalamnya, sehingga akan mampu menghasilkan lulusan yang lebih berkualitas juga. Dalam mewujudkan lulusan yang berkualitas guru tidak dapat melakukan semuanya sendiri tanpa adanya dukungan dan bantuan dari kepala sekolah sebagai pemimpin. Anizah dan Maretta (2017) menyatakan bahwa menjadi seorang guru profesional tidak akan pernah terwujud dengan sendirinya tanpa adanya upaya untuk mengembangkan dan meningkatkannya. Salah satu upaya tersebut yaitu adanya dukungan kepala sekolah, karena kepala sekolah yang mempunyai peran langsung dalam pelaksanaan program-program sekolah.

Berdasarkan teori Latham, dkk. (dalam Krismiyati, 2017) terdapat tiga indikator yang dapat digunakan seorang kepala sekolah dalam upaya meningkatkan mutu sekolah melalui pengembangan kualitas guru. Tiga indikator tersebut meliputi (1) motivasi (2) kepribadian dan (3) keterampilan. Berikut adalah diagram skema pemikiran pengembangan kualitas guru dalam upaya meningkatkan mutu sekolah dasar (Gambar 1). Hasil analisis berdasarkan gambar 1 menunjukkan bahwa setiap kepala sekolah sebagai seorang pemimpin pasti mempunyai berbagai cara, upaya dan atau strategi dalam meningkatkan mutu sekolahnya. Peningkatan mutu sekolah adalah faktor utama yang sangat ditekankan dalam pembangunan Pendidikan. Akan tetapi, dari keseluruhan aspek atau komponen pendidikan yang menjadi penentu capaian kualitas lulusan adalah guru. Tentunya dengan bantuan dan dukungan kepala sekolah, tanpa bantuan dan dukungan seorang 
pemimpin maka guru tidak akan dapat menghasilkan lulusan yang berkualitas. Oleh karena itu, perlunya upaya dalam pengembangan kualitas guru melalui tiga indikator tersebut.

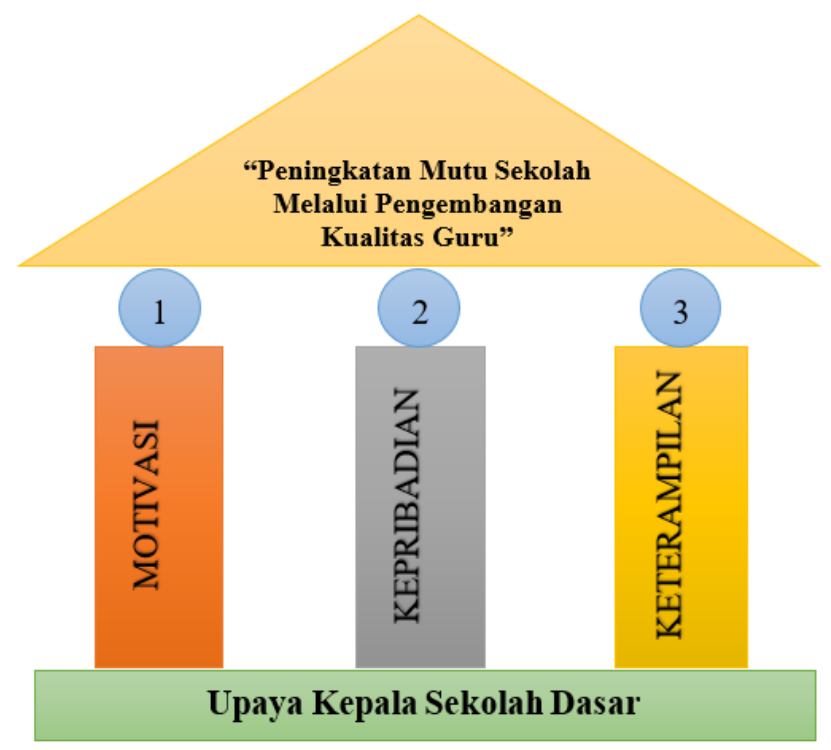

\section{Gambar 1. Diagram Skema Pemikiran Pengembangan Kualitas Guru dalam Upaya Meningkatkan Mutu Sekolah Dasar}

Pertama, meningkatkan motivasi guru sekolah dasar sehingga guru terdorong dalam menggunakan potensinya semaksimal mungkin dalam kegiatan pembelajaran, caranya dengan pemberian penghargaan (reward) kepada guru berprestasi (Simarmata, 2014). Kedua, memantapkan kepribadian guru sehingga tidak gampang marah, mampu mengendalikan kegiatan pembelajaran yang sesuai dengan kebutuhan dan kondisi peserta didik saat ini, dan memiliki jiwa seorang guru. Caranya, seorang kepala sekolah dapat mengaitkan dengan fungsi kepala sekolah sebagai seorang supervisor dimana kepala sekolah mampu memecahkan persoalan, membantu dan melayani guru dalam meningkatkan kemampuan guru, disini kepala sekolah harus memegang salah satu prinsip seorang supervisor yaitu berorientasi pada hubungan kemanusiaan yang harmonis (supervisi kolegial). Sehingga guru dapat terbuka, jujur, antusias dalam menuangkan permasalahan pembelajaran.

Ketiga, meningkatkan keterampilan guru dalam mengajar. Seorang guru dituntut terampil dalam mengajar, karena motivasi tinggi dan kepribadian baik tidak mencukupi untuk menghasilkan lulusan yang berkualitas. Safitri dan Sontani (2016) menyatakan keterampilan guru dalam mengajar dapat diperoleh dari pendidikan dan berbagai pelatihan. Kepala sekolah dalam hal ini membagi dengan adanya dua kegiatan pengembangan dan pelatihan yaitu (1) kegiatan internal seperti sharing sesama guru atau guru dengan kepala sekolah, dan (2) kegiatan eksternal seperti 
KKG (Kelompok Kerja Guru) biasanya dapat berbentuk workshop, seminar, dengan berbagai macam tema yang diangkat dan mendatangkan narasumber ahli dari luar.

Meskipun demikian, hasil di lapangan menunjukkan bahwa tidak semua guru dapat memenuhi tiga indikator tersebut, dan adanya beberapa hambatan yang dihadapi kepala sekolah dalam upayanya meningkatkan mutu sekolah dasar melalui pengembangan kualitas guru. Dengan demikian, pengembangan kualitas guru dalam meningkatkan mutu sekolah dasar harus terus dikembangkan dan disesuaikan dengan perkembangan zaman. Agar mempermudah kepala sekolah dalam pengadaan program pengembangan kualitas guru melalui workshop, pada gambar 2 berikut, disajikan flowchart pengadaan workshop peningkatan keterampilan guru sekolah dasar.

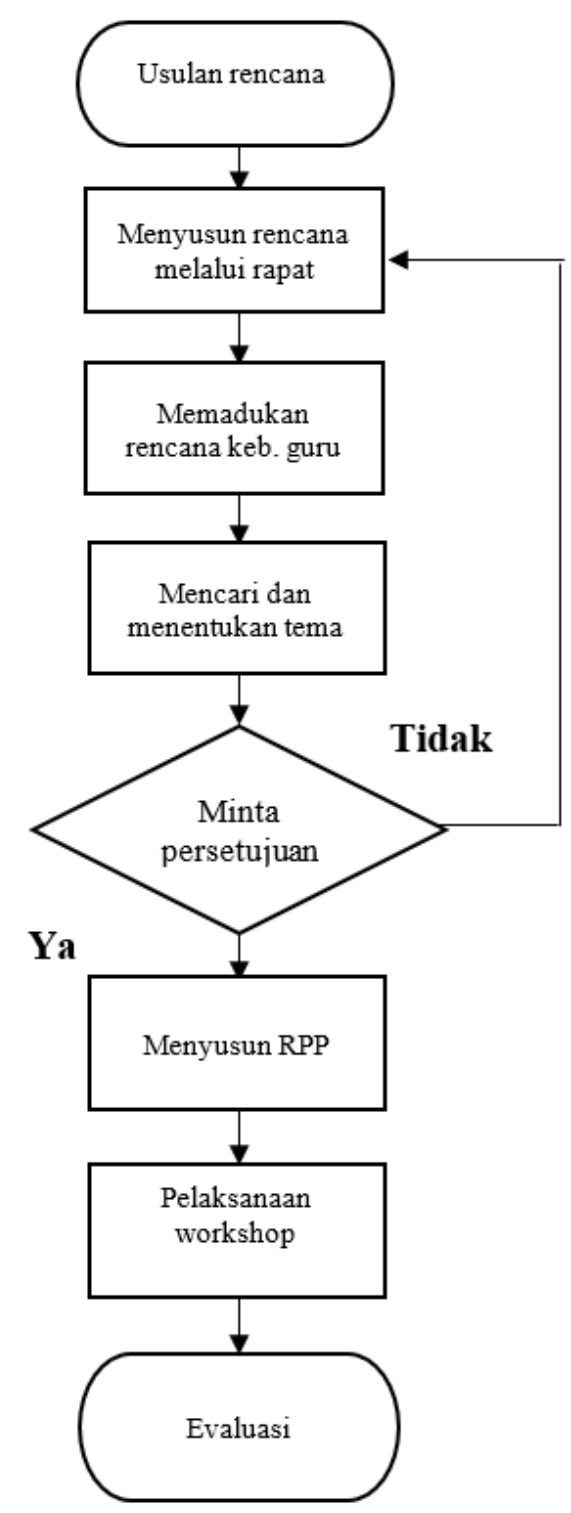

Gambar 2. Flowchart Pengadaan Workshop Peningkatan Keterampilan Guru Sekolah Dasar 


\section{Hakikat Pengembangan Guru dalam Upaya Peningkatan Mutu Sekolah Dasar}

Melihat persaingan global bidang pendidikan saat ini di era revolusi industri 4.0, pengembangan guru dinilai sangat penting terutama dalam upaya peningkatan mutu pendidikan. Mengapa demikian? Hal ini karena guru merupakan unsur sangat penting dalam pembelajaran di samping unsur yang lainnya. Meskipun guru bukan satu-satunya faktor penentu mutu sekolah, akan tetapi guru adalah sentral pembelajaran yang akan menciptakan berbagai inovasi sehingga menjadi penyebab baik buruknya mutu lulusan sekolah (Ruhana, 2012). Anizah dan Maretta (2017) menyatakan bahwa dalam meningkatkan mutu sekolah komponen yang paling berperan adalah guru sebagai tenaga pendidik, dimana guru memiliki peran strategis untuk membentuk semua pengetahuan, keterampilan dan karakter peserta didik di sekolah. Sehingga dapat disimpulkan bahwa tenaga pendidik yaitu guru mempunyai peran utama dalam menghasilkan kualitas lulusan sekolah. Berkualitas tidaknya output sekolah dapat dilihat dari mutu pendidiknya. Maruli (2014) menyatakan bahwa peserta didik yang memiliki guru yang baik maka mereka akan belajar lebih banyak daripada peserta didik yang memiliki guru berkinerja buruk. Kualitas guru tercermin dalam kinerja mereka di kelas, yaitu kualitas pengajaran dan di luar kelas.

Kepala sekolah sebagai pemimpin sudah seharusnya secara kontinyu melakukan penekanan terhadap berbagai program pengembangan kualitas guru di sekolah dasar. Jusuf (2005) menyatakan bahwa semua guru harus diberi pengembangan berkelanjutan dengan dukungan setepat mungkin. Dapat disimpulkan bahwa selain memberikan pengembangan berkelanjutan kepada guru, kepala sekolah juga berperan dalam mendukung program pengembangan kualitas gurunya.

\section{Upaya Kepala Sekolah dalam Meningkatkan Mutu Sekolah Dasar Melalui Pengembangan Guru}

Teori Latham, dkk. (dalam Krismiyati, 2017:47) menyatakan bahwa program pengembangan dan pelatihan mempunyai berbagai tujuan antara lain untuk meningkatkan kesadaran diri personal, meningkatkan keterampilan dalam berbagai bidang keahlian, dan untuk meningkatkan motivasi diri dalam mengemban tugas dengan memuaskan. Sehingga dapat disimpulkan bahwa ada tiga indikator yang dapat digunakan seorang kepala sekolah dalam upaya meningkatkan mutu sekolah melalui pengembangan kualitas guru, yang meliputi (1) motivasi (2) kepribadian dan (3) keterampilan.

\section{Motivasi}

Simarmata (2014) menyatakan bahwa motivasi merupakan suatu usaha dalam mendorong, menggerakkan seseorang atau kelompok tertentu agar dapat melakukan sesuatu untuk mencapai tujuan yang diinginkan. Seorang guru seharusnya mempunyai motivasi diri dalam mencapai tujuan 
pembelajaran di sekolah. Apabila seorang guru mempunyai motivasi tinggi dalam mengajar maka otomatis potensi yang ada di dalam diri guru akan semaksimal mungkin dikeluarkan. Motivasi dapat muncul dari dalam diri guru itu sendiri, tetapi banyak diantaranya motivasi dapat muncul apabila didorong dari luar seperti dari guru lain atau dari kepala sekolah.

Kepala sekolah sebagai seorang pemimpin di sekolah perlu memiliki strategi dalam meningkatkan motivasi para gurunya. Upaya kepala sekolah di SD Negeri Gondowangi 3 dalam memberi motivasi kepada para pendidik sekolah dasar antara lain, (1) memberi semangat dalam mengajar. Menurut Bapak S hal ini diperlukan, karena kalau sudah semangat maka akan mudah untuk diberikan motivasi secara terus menerus. (2) Mencari kelemahan atau kekurangan yang ada pada masing-masing guru dalam mengajar kemudian didiskusikan kelemahan tersebut. Disini kepala sekolah selalu memberi kesempatan guru untuk mengutarakan masalah-masalah yang dihadapi. (3) Mencari solusi atas berbagai kelemahan yang dimiliki setiap guru untuk mendapatkan jalan yang terbaik. (4) Menerapkan solusi tersebut dalam mengajar di kelas. Dalam hal ini kepala sekolah sekali waktu melihat langsung apakah terdapat perkembangan dan perubahan atau sebaliknya. Selanjutnya, (5) kepala sekolah sesekali memberi reward untuk guru yang mempunyai kinerja bagus tujuannya untuk memotivasi guru-guru lainnya. Simarmata (2014) menyatakan bahwa salah satu bentuk upaya kepala sekolah dalam meningkatkan motivasi yaitu dengan pemberian penghargaan kepada guru. Penghargaan ini dapat diberikan pada guru yang mempunyai perilaku positif dan memiliki prestasi lainnya, seperti pemberian piagam yang dapat diserahkan pada momen-momen tertentu, misalnya ketika upacara bendera dihadapan seluruh warga sekolah.

Meskipun motivasi guru di SD Negeri Gondowangi 3 sudah tinggi karena dedikasinya sebagai guru atau adanya tuntutan dari pekerjaan sehingga cara mengajarnya juga antusias, kepala sekolah tetap memberikan dorongan dalam memotivasi setiap guru untuk terus mempertahankan atau bahkan meningkatkan semangatnya dalam mengajar. Simarmata (2014) menyatakan tanpa adanya motivasi kerja yang baik maka suasana sekolah dan kelas akan menjadi kurang kondusif dalam proses pembelajaran. Dengan adanya motivasi tinggi seorang guru dalam mengajar maka guru akan menjalankan semua job disk sesuai dengan kecakapan dan kemampuan yang dimilikinya sehingga diharapkan mampu mewujudkan tujuan pendidikan (Safitri dan Sontani, 2016). Selain berbagai upaya kepala sekolah dalam meningkatkan motivasi guru yang telah dijelaskan di atas, pemerintah daerah Kabupaten Malang juga memberikan penghargaan terhadap guru berprestasi dan kepala sekolah berprestasi se-kabupaten. Setiap sekolah mengirimkan salah satu guru yang paling berprestasi yang nantinya akan berkompetisi pada tingkat kecamatan. Setelah dipilih dan ditentukan di tingkat kecamatan maka akan dikirim untuk berkompetisi di 
tingkat kabupaten. Apabila pada tingkat kabupaten belum berhasil, maka guru atau kepala sekolah yang sudah mewakili se-kecamatan tetap diberikan reward.

Kepala sekolah sebagai seorang pemimpin paling tidak dapat menerapkan 3 pilar pendidikan menurut Ki Hajar Dewantara yaitu (1) ing ngarso sung tulodo, (2) ing madyo mangun karso, dan (3) tut wuri handayani. Ketiga pilar ini dapat dijadikan kepala sekolah sebagai strategi dalam mengembangkan motivasi guru (Simarmata, 2014).

\section{Kepribadian}

Nahampun (2017) menyatakan bahwa seorang guru harus mempunyai kepribadian yang mantap sehingga mampu dalam mengendalikan kegiatan pembelajaran yang sesuai dengan kebutuhan dan kondisi peserta didik saat ini serta seorang guru harus menjadi sumber inspirasi bagi peserta didik. Menurut penuturan Kepala SD Negeri Gondowangi 3, kepribadian yang semestinya dimiliki oleh seorang pendidik sekolah dasar, antara lain (1) harus menjiwai jiwa seorang pendidik, dimana guru juga berperan sebagai orang tua. Menurut penuturan beliau, apabila sebagai seorang pendidik dapat mempunyai sambung rasa dengan peserta didik, maka ini akan menunjang keberhasilan belajar peserta didik. (2) Peserta didik akan memperhatikan gurunya apabila guru juga senantiasa memperhatikan peserta didiknya. Jadi guru tidak menyelesaikan tanggungjawab hanya sebagai pengajar tetapi kedekatan guru dan peserta didik harus diperhatikan. Tanpa perhatian seorang guru maka peserta didik juga tidak akan menghiraukan. (3) Setiap peserta didik mempunyai kelemahan dalam belajar sehingga seorang guru semestinya mampu menggali berbagai penyebab atas kelemahan tiap peserta didiknya. Selanjutnya, (4)Seorang guru harus dapat menjadi pemimpin untuk peserta didiknya yang terkadang harus bersifat otoriter seperti tentara yang disiplin dan tegas, tetapi tetap atas dasar kasih sayang terhadap peserta didiknya.

Pada kenyataannya di lapangan, masih ada guru yang belum memiliki kepribadian demikian. Hal ini dikarenakan setiap guru mempunyai kelemahannya masing-masing. Berdasarkan penuturan Bapak S, banyak guru yang kurang profesional dalam mengajar, terutama guru-guru yang masih muda, yang mempunyai emosional tinggi, seperti permasalahan keluarga yang dibawa ke sekolah. Hal ini mengakibatkan guru marah secara berlebihan di kelas yang berdampak kepada peserta didik. Upaya kepala sekolah ketika melihat guru yang bertindak kasar terhadap peserta didik, yaitu dengan mengajak bicara face to face di ruang kepala sekolah. Disini kepala sekolah menerapkan kepemimpinan yang berorientasi terhadap hubungan sesama manusia, yaitu hubungan yang harmonis dengan guru. Kepala sekolah menempatkan dirinya sebagai orangtua di hadapan guru meskipun pada dasarnya guru merupakan mitra kerja seorang kepala sekolah. Tujuannya agar antara kepala sekolah dan guru mempunyai sambung rasa sehingga apapun persoalan pembelajaran yang dirasakan oleh guru dapat diungkapkan secara terbuka. Hal demikian dapat dikaitkan dengan fungsi kepala sekolah sebagai seorang supervisor yang mampu memecahkan 
persoalan, membantu dan melayani guru dalam meningkatkan kemampuan guru. Hal yang ditunjukkan oleh kepala sekolah disini adalah beliau memegang salah satu prinsip seorang supervisor, yaitu berorientasi pada hubungan kemanusiaan yang harmonis/supervisi kolegial (Gunawan, 2015).

Apabila seorang guru dapat terbuka, maka kepala sekolah otomatis dapat secara langsung memberikan solusi, masukan terhadap permasalahan guru tersebut. Dimana semestinya seorang guru sebagai pendidik tetap harus lemah lembut, sabar, dan profesional dalam mengajar bagaimanapun permasalahan yang dihadapi. Nahampun (2017) menyatakan dimana undangundang tentang guru dan dosen mengharuskan para guru mempunyai kemampuan individu yang dapat mencerminkan pribadi mantab dan stabil, arif dan bijaksana, berwibawa, dewasa, memiliki akhlak mulia, dan dapat menjadi teladan peserta didik. Profesi guru sekarang rentan dihadapkan oleh berbagai persoalan terhadap peserta didik, seperti adanya permasalahan beberapa guru terhadap peserta didik yang dibawa ke ranah hukum. Hal ini disebabkan oleh perasaan tidak terima orangtua peserta didik terhadap hukuman yang diberikan guru kepada peserta didik tersebut, contohnya mencubit, meskipun dengan tujuan yang baik, yaitu untuk memunculkan efek jera.

Berdasarkan penuturan Bapak S, hal demikian biasa terjadi karena era sekarang sudah jauh berbeda dengan dulu, sehingga gaya orangtua sebagai wali murid dulu dan sekarang juga berbeda. Sebagai kepala sekolah, dengan adanya permasalahan yang telah dijelaskan di atas harus terus berupaya memberi masukan dan saran kepada para guru untuk dapat mengontrol emosi. Guru diingatkan untuk tidak menghukum peserta didik secara fisik terlebih sampai berbekas hanya karena amarah sesaat. DIsamping itu, seorang guru harus menempatkan dirinya sebagai orangtua teladan yang memiliki kasih sayang tulus kepada semua peserta didiknya. Anizah dan Maretta (2017) menyatakan bahwa menjadi seorang guru profesional tidak akan pernah terwujud dengan sendirinya tanpa adanya upaya untuk mengembangkan dan meningkatkannya, salah satunya yaitu adanya dukungan kepala sekolah karena kepala sekolah yang mempunyai peran langsung dalam pelaksanaan program-program sekolah.

\section{Keterampilan}

Safitri dan Sontani (2016) menyatakan bahwa keterampilan mengajar merupakan suatu tindakan dalam memfasilitasi kegiatan pembelajaran peserta didik baik secara langsung maupun tidak langsung. Keterampilan guru dalam mengajar dapat diperoleh dari pendidikan dan berbagai pelatihan. Keterampilan yang seharusnya dimiliki oleh seorang guru sekolah dasar berdasarkan penuturan Bapak S antara lain (1) gaya mengajar. Pesatnya perkembangan teknologi saat ini menuntut seorang guru harus mempunyai gaya mengajar yang dapat membuat peserta didik tertarik untuk belajar seperti penyampaian materi dengan bahasa lugas, gamblang sehingga mudah dipahami peserta didik. (2) Guru harus menyiapkan media pembelajaran yang menarik, karena 
apabila media belajar tidak menarik, maka peserta didik tidak akan tertarik dan memperhatikan. (3) Metode mengajar guru seharusnya tidak monoton, misalnya hanya ceramah. Sesekali peserta didik diajak praktek langsung ke lapangan, seperti saat pelajaran IPA dengan mengambil tema "Mengenal Berbagai Jenis Daun". Pada pembelajaran di Tema ini, peserta didik diajak langsung mengidentifikasi berbagai jenis daun di lapangan, sehingga selain menarik, pembelajaran seperti ini akan mempermudah guru untuk mejelaskan dan mempermudah peserta didik untuk lebih memahami materi. Setelah mengidentifikasi berbagai jenis daun, peserta didik diwajibkan membuat laporan yang kemudian hasil laporan tersebut didiskusikan di kelas. Disini seorang guru juga dituntut untuk memahami berbagai karakter peserta didik agar mempermudah tercapainya tujuan pembelajaran.

Anizah dan Maretta (2017) menyatakan bahwa guru yang profesional tidak sekedar memiliki penguasaan berbagai ilmu pengetahuan. Guru yang profesional juga mampu dalam memotivasi peserta didik, memberikan pengajaran secara efektif, dan tentunya mempunyai keterampilan tinggi. Kenyataannya di lapangan, tidak semua guru mempunyai keterampilan tinggi dalam mengajar. Sehingga upaya Bapak S selaku kepala sekolah dalam melatih dan mengembangkan keterampilan guru di sekolah dasar antara lain (1) mengadakan kegiatan internal sekolah yaitu setiap satu minggu sekali. Mengadakan sharing atau diskusi bersama yang dilakukan dalam bentuk rapat, dalam forum ini kepala sekolah menanyakan berbagai kesulitan apa saja yang dihadapi dalam pembelajaran. Selanjutnya kepala sekolah dapat memetakan kelebihan dan kekurangan setiap guru, maka kepala sekolah menugaskan kepada guru yang mempunyai kelebihan dalam arti baik dalam pembelajaran untuk dapat membantu guru-guru yang mempunyai kesulitan dalam mengajar akan tetapi tetap pada bimbingan Kepala Sekolah. Berikutnya, (2) mengadakan kegiatan eksternal sekolah, yaitu kegiatan ditingkat gugus yang disebut KKG (Kelompok Kerja Guru) dimana setiap satu bulan sekali diadakan pertemuan. Pada forum ini guru mendiskusikan berbagai permasalahan dalam mengajar dengan mendatangkan guru yang sudah lama berpengalaman kemudian mengajak guru lainnya untuk mendengarkan, mengamati dan menemukan solusi. Biasanya pelatihan dan pengembangan ini berbentuk workshop, seminar, dengan berbagai macam tema yang diangkat.

Pelatihan-pelatihan seperti ini sangat diperlukan guru dalam upaya pengembangan diri, karena tentunya guru tidak dapat hanya mengandalkan pengetahuan teoritis yang telah didapatkan dari perguruan tinggi. Semua dapat berubah secara drastis ketika sudah berkecimpung di dunia persekolahan sesungguhnya. Kepala sekolah dalam hal ini secara terus menerus memastikan adanya berbagai pelatihan dan pengembangan kualitas guru karena pengetahuan semakin maju dan berkembang. Hal ini didukung dengan adanya era revolusi industri dimana guru selalu dituntut untuk dapat mengikuti perkembangan yang ada. Jusuf (2005) menyatakan guru profesional harus mengerti perubahan dalam teknologi informasi, pengaruhnya terhadap tempat kerja dan 
masyarakat, potensi mereka untuk mengatasi pembelajaran seumur hidup, kebutuhan di tempat kerja, serta konsekuensi dari penyalahgunaan. Bicaj (2014) menyatakan bahwa guru merupakan tokoh kunci reformasi pendidikan, harus selalu siap untuk berbagai perubahan. Dengan demikian, guru profesional harus dapat menggunakan sumber daya telekomunikasi dan akses informasi untuk mendukung pembelajaran. Apabila guru tidak bersikap demikian, maka dampaknya sekolah tentunya juga akan tertinggal.

Kepala sekolah pada penelitian ini dalam upayanya meningkatkan mutu sekolah melalui pengembangan kualitas guru sudah menerapkan tiga indikator pengembangan kualitas guru, antara lain motivasi, kepribadian, dan keterampilan. Hasil di lapangan menemukan bahwa tidak semua guru memenuhi tiga indikator tersebut, dan adanya beberapa hambatan yang dihadapi. Salah satunya pada perbandingan gaji dan tunjangan antara guru honorer/non PNS dengan guru PNS. Gaji guru non PNS dirasa rendah, sehingga mempengaruhi etos kerja yang akhirnya berdampak pada kualitas guru tersebut. Jusuf (2005) menyatakan bahwa guru dapat berkonsentrasi dan menjadi guru yang menginspirasi dalam tugas profesional mereka, apabila kesejahteraan mereka cukup terpenuhi. Menghadapi hal demikian, upaya kepala sekolah untuk terus berusaha meningkatkan mutu sekolahnya melalui pengembangan guru dengan pemberian tambahan kesejahteraan bagi guru non PNS. Besaran tambahan ini diperoleh dari tunjangan diluar gaji guru PNS yang dikoordinir oleh kepala sekolah untuk diberikan guru non PNS, yang tentunya dengan persetujuan semua guru PNS sebelumnya. Tujuan pemberian ini untuk membantu penambahan gaji guru non PNS karena di sekolah dasar umumnya banyak guru non PNS daripada guru PNS. Dengan demikian pengembangan kualitas guru dalam meningkatkan mutu sekolah dasar harus terus dikembangkan.

\section{SIMPULAN DAN SARAN}

\section{Simpulan}

Upaya kepala sekolah dasar dalam meningkatkan mutu sekolah melalui pengembangan kualitas guru pada penelitian ini adalah dengan menekankan tiga indikator antara lain (1) motivasi, memotivasi guru dengan menggunakan metode langsung (direct motivation) seperti pemberian penghargaan (reward), (2) kepribadian, mampu mengendalikan kegiatan pembelajaran yang sesuai dengan kebutuhan dan kondisi peserta didik, sabar dan memiliki tanggungjawab. Disini seorang kepala sekolah dapat mengaitkan dengan fungsi kepala sekolah sebagai seorang supervisor (penerapan supervisi kolegial). Hal ini dilakukan sehingga guru dapat terbuka, jujur, antusias dalam menuangkan permasalahan pembelajaran. Selanjutnya, (3) keterampilan, kepala sekolah dalam hal ini membagi dengan adanya dua kegiatan pengembangan dan pelatihan yaitu kegiatan internal seperti sharing sesama guru atau guru dengan kepala sekolah, dan kegiatan eksternal seperti KKG (Kelompok Kerja Guru) biasanya dapat berbentuk workshop, seminar, dengan 
berbagai macam tema yang diangkat dan mendatangkan narasumber ahli dari luar. Meskipun demikian hasil di lapangan menemukan tidak semua guru dapat memenuhi tiga indikator tersebut, sehingga pengembangan kualitas guru dalam meningkatkan mutu sekolah dasar harus terus dikembangkan dan disesuaikan dengan perkembangan zaman.

\section{Saran}

Kepala sekolah dalam menentukan strategi atau upaya peningkatan mutu sekolah melalui pengembangan kualitas guru harus benar-benar memperhatikan kebutuhan guru yang saat itu diperlukan dalam meningkatkan potensi dan kemampuan dalam mengajar, melihat perkembangan berbagai ilmu pengetahuan dan teknologi informasi yang semakin pesat. Oleh karena itu, seorang kepala sekolah juga harus mempunyai keahlian dan kemampuan dalam menghadapi berbagai tantangan di era global saat ini serta dapat mengambil dan mengembangkan peluang yang ada untuk kemajuan sekolah.

\section{DAFTAR RUJUKAN}

Anizah \& Maretta (2017). Kepemimpinan Efektif Kepala Sekolah dalam Mengembangkan Profesionalisme Guru. Jurnal Manajemen, Kepemimpinan, dan Supervisi Pendidikan, 2(1).

Bicaj, A., \& Treska, T. (2014). The Effect of Teacher Professional Development in Raising the Quality of Teaching (Pilot Research). Academic Journal of Interdisciplinary Studies, 3(6), 369.

Fadhli, M. (2017). Manajemen peningkatan mutu pendidikan. Tadbir: Jurnal Studi Manajemen Pendidikan, 1(2), 215-240.

Gunawan, I. (2015). Mengembangkan Alternatif-alternatif Pendekatan dalam Pelaksanaan Supervisi Pengajaran. Manajemen Pendidikan, 24(6), 467-482.

Ilyas, I. (2016). Pendidikan Karakter Melalui Homeschooling. Journal of Nonformal Education, 2(1). https://journal.unnes.ac.id/nju/index.php/jne/article/download/5316/4226.

Juanda, J. (2010). Peranan Pendidikan Formal dalam Proses Pembudayaan. Lentera Pendidikan: Jurnal Ilmu Tarbiyah dan Keguruan, 13(1), 1-15.

Jusuf, H. (2005). Improving Teacher Quality, a Keyword for Improving Education Facing Global Challenges. Turkish Online Journal of Educational Technology-TOJET, 4(1), 33-37. http://www.tojet.net/articles/v4i1/414.pdf.

Krismiyati, K. (2017). Pengembangan Sumber Daya Manusia dalam Meningkatkan Kualitas Pendidikan di SD Negeri Inpres Angkasa Biak. Jurnal Office Volume, 3(1), 43-50. http://ojs.unm.ac.id/index.php/jo/article/viewFile/3459/1951.

Makbuloh, D. (2016). Pendidikan Islam dan Sistem Penjaminan Mutu Menuju Pendidikan Berkualitas di Indonesia. Jakarta: Rajawali Pers.

Maruli, S. (2014). Quality in Teaching: A review of literature. International Journal of Education and Research, 2(12), 193-200.

Nahampun, D. (2017). Kompetensi Kepribadian Guru dalam Pelaksanaan Pembelajaran Anak Autis di SLB C Karya Bhakti Purworejo. Widia Ortodidaktika, 6(5), 538-546. http://journal.student.uny.ac.id/ojs/index.php/plb/article/viewFile/7783/7410. 
Nwabueze, A. I. (2016). Resources in education. Economics of education: Expository issues, 186205.

Ruhana (2012). Pengembangan Kualitas Sumber Daya Manusia VS Daya Saing Global. Jurusan Administrasi Bisnis FIA Universitas Brawijaya Malang. Jurnal Profit, 6(1). https://ejournalfia.ub.ac.id/index.php/profit/article/viewFile/134/348.

Safitri \& Sontani (2016). Keterampilan Mengajar Guru dan Motivasi Belajar Siswa Sebagai Determinan terhadap Hasil Belajar. Jurnal Pendidikan Manajemen Perkantoran, 1(1), 144-153. http://ejournal.upi.edu/index.php/jpmanper/article/view/3258/0.

Simarmata, R. H. (2014). Upaya Peningkatan Motivasi Kerja Guru Sekolah Dasar. Jurnal Bahana Manajemen Pendidikan, 2(1), 654-660.

Sonhadji, A. (2014). Manusia, Teknologi, dan Pendidikan Menuju Peradaban Baru. Malang: Universitas Negeri Malang. 